\title{
Unmet need for family planning and factors associated among women living with HIV in Oromia regional state, Ethiopia
}

Dereje Bayissa Demissie ${ }^{1,2^{*}} \mathbb{C}$, Gizachew Abdissa Bulto ${ }^{3}$ and Rose Mmusi-Phetoe ${ }^{4}$

\begin{abstract}
Objectives: The purpose of this study was to determine the prevalence of the unmet need and identifying factors associated with the unmet need among women of reproductive age living with HIV in Oromia regional state, Ethiopia. One critical component of both a full range of contraceptives and satisfying demand for family planning with HIV services all women living with HIV is the appropriate model for HIV therapy, HIV prevention, and care with family planning services in a resource-limiting area like Ethiopia.

Methods: Health facility-based cross-sectional study design was conducted among women living with HIV attending ART clinics in the special zone of, Oromia regional state, by simple random sampling was used to select 654 respondents. Both bivariate and multivariable logistic regressions analysis was used to identify at adjusted odds ratio (AOR) with $95 \% \mathrm{Cl}$ in the final model.
\end{abstract}

Result: The study assessed the magnitude of demand for family planning among HIV-infected women and established that the demand was 630 (96.3\%), of which 100 (16\%) of women of reproductive age living with HIV had unmet needs for family planning while attending monthly ART clinic drug refilling and follow up. This study identified that factors found to be associated with met needs for family planning among women of reproductive age living with HIV attending ART/PMTC were discussions with healthcare providers (AOR $=4.33,95 \% \mathrm{Cl}$ 2.56-7.32), previous pregnancy ( $A O R=3.07,95 \% \mathrm{Cl} 1.84-5.12)$; future fertility desire $(A O R=2.15,95 \% \mathrm{Cl} 1.31-3.51)$; having sexual partners $(A O R=5.26,95 \% \mathrm{Cl} 1.79-15.5)$ and the number of the sexual partner (one) ( $A O R=7.24,95 \% \mathrm{Cl} 1.82-28.74$ ) were identified independent predictors of met needs for family planning.

Conclusion: The overall demand for family planning was $96 \%$ among the women living with HIV, and that 16\% of women had an unmet need for family planning. The authors conducted a logistic regression and find various dependent variables that are associated with the met need for family planning services, such as having discussions with healthcare providers, having a partner and previous pregnancy; future fertility desire, the last pregnancy being intended. These results are interpreted to suggest that clear policy implications of family planning must be better integrated into ART clinics.

Keywords: Modern contraceptives, Family planning, Met need, Unmet needs, Women living with HIV

*Correspondence: dereje.bayissa@sphmmc.edu.et

1 Department of Health Studies, College of Human Science, University of South Africa, Regional Learning Office Ethiopia, Addis Ababa, Ethiopia

Full list of author information is available at the end of the article permits use, sharing, adaptation, distribution and reproduction in any medium or format, as long as you give appropriate credit to the original author(s) and the source, provide a link to the Creative Commons licence, and indicate if changes were made. The images or other third party material in this article are included in the article's Creative Commons licence, unless indicated otherwise in a credit line to the material. If material is not included in the article's Creative Commons licence and your intended use is not permitted by statutory regulation or exceeds the permitted use, you will need to obtain permission directly from the copyright holder. To view a copy of this licence, visit http://creativecommons.org/licenses/by/4.0/. The Creative Commons Public Domain Dedication waiver (http://creativeco mmons.org/publicdomain/zero/1.0/) applies to the data made available in this article, unless otherwise stated in a credit line to the data. 


\section{RESUMO}

Objetivos: O objetivo deste estudo foi determinar a prevalência da necessidade não atendida e identificar os fatores associados à necessidade não atendida entre mulheres em idade reprodutiva vivendo com HIV no estado regional de Oromia, Etiópia. Um componente crítico de uma gama completa de anticoncepcionais e satisfazer a demanda de planejamento familiar com serviços de HIV para todas as mulheres que vivem com HIV é o modelo apropriado para terapia de HIV, prevenção do HIV e cuidados com serviços de planejamento familiar em uma área com recursos limitados como a Etiópia.

Métodos: $O$ desenho de um estudo transversal baseado em unidades de saúde foi conduzido entre mulheres vivendo com HIV atendidas em clínicas de TARV na zona especial do estado de Oromia Regional, por amostragem aleatória simples foi usada para selecionar 654 respondentes. As análises de regressão logística bivariada e multivariada foram utilizadas para identificar a odds ratio ajustada (AOR) com IC de 95\% no modelo final.

Resultado: o estudo avaliou a magnitude da demanda de planejamento familiar entre mulheres infectadas pelo HIV e estabeleceu que a demanda era de 630 (96,3\%), das quais 100 (16\%) das mulheres em idade reprodutiva vivendo com HIV tinham necessidades não atendidas de planejamento familiar enquanto comparecia ao reabastecimento e acompanhamento de medicamentos da clínica ART mensal. Este estudo identificou que os fatores encontrados associados ao atendimento das necessidades de planejamento familiar entre mulheres em idade reprodutiva vivendo com HIV em TARV / PMTC foram discussões com profissionais de saúde (AOR = 4,33, IC 95\%: 2,56-7,32), gravidez anterior ( $\mathrm{AOR}=3.07$, IC 95\% 1.84-5.12); desejo futuro de fertilidade ( $\mathrm{AOR}=2.15$, IC 95\%: 1.31-3.51); ter parceiros sexuais $(A O R=5.26$, IC 95\% 1.79-15.5) e o número do parceiro sexual (um) ( $A O R=7.24$, IC 95\% 1.82-28.74) foram preditores independentes identificados de necessidades atendidas de planejamento familiar.

Conclusão: A demanda geral de planejamento familiar foi de 96\% entre as mulheres que vivem com HIV e 16\% das mulheres tinham uma necessidade não atendida de planejamento familiar. Os autores realizaram uma regressão logística e encontraram várias variáveis dependentes que estão associadas ao atendimento da necessidade de serviços de planejamento familiar, como discussões com profissionais de saúde, ter companheiro e gravidez anterior; desejo de fertilidade futura, pretendendo-se a última gravidez. Esses resultados são interpretados para sugerir que as implicações políticas claras do planejamento familiar devem ser melhor integradas às clínicas de TARV.

Palavras-chave: Contraceptivos modernos, planejamento familiarplanejamento familiar, necessidades atendidas, necessidades não atendidas, mulheres vivendo com HIV

\section{Plain Language summary}

The overall demand for family planning was $96 \%$ among the women living with HIV, and that $16 \%$ of women had an unmet need for family planning. The authors conducted a logistic regression and find various dependent variables that are associated with the met need for family planning services, such as having discussions with healthcare providers, having a partner and previous pregnancy; future fertility desire, the last pregnancy being intended. It was established that high met need demand for family planning among HIV-infected women. These results are interpreted to suggest that clear policy implications of family planning must be better integrated into ART clinics an important conclusion of this study result. Policymakers would be better considers the future developments of national guidelines/ strategies and training modules of family planning and HIV would be integrated family planning services into facilitybased care for women living with HIV should consider these identified factors to increase the availability of family planning among women of reproductive age living with HIV. After the implementation of the final strategic plan, the integration of family planning and HIV services should lead to an increase in the utilization of family planning, dual contraceptive methods, the need for family planning being met, prevent repeated unwanted pregnancy, and offer HIV services. This will ultimately improve the quality of life of reproductive-aged women, the community, and families at large. Policymakers would better establish women-centered integrated family planning with HIV service could facilitate that the met need demand for family planning services of reproductive age women living with HIV.

\section{Introduction}

The World Health Organization (WHO) has called on developing countries to ensure that women living in HIV-infected areas have access to a range of contraceptives as well as safe pregnancy, especially for those who are at risk of developing HIV and other sexually 
transmitted diseases [1]. Three key principles guided United States government's global health policy to meet the family planning demands of HIV-positive women are an emphasis on reproductive rights via voluntarism and informed choice, quality service provision through evidence-based programming, and the creation of partnerships [2].

Women with unmet need are those who are fecund and sexually active but are not using any method of contraception, and report not wanting any more children or wanting to delay the next child. The concept of unmet need points to the gap between women's reproductive intentions and their contraceptive behavior [3].

In many areas of the world where HIV prevalence is high, rates of unintended pregnancy and unsafe abortions are high. Of all pregnancies worldwide in $2008,41 \%$ were reported as unintended or unplanned, and approximately $50 \%$ of these ended in abortion [4].

In 2012 it was estimated that in sub-Saharan Africa, 53 million women who wanted to avoid pregnancy were not using any family planning method [5]. Thus, the unmet need for contraception among women living with HIV in sub-Saharan Africa is high, with $66-92 \%$ of women reporting not wanting another child (now or ever), but only $20-43 \%$ of them using contraception [6]. The prevalence of unmet needs for family planning thus remains unacceptably high among women in sub-Saharan Africa, including those living with HIV, even if they are involved in HIV treatment programs [5].

According to the 'Ethiopia Demographic and Health Survey' (EDHS) of 2016 indicator, 28.9\% of currently married women in the Oromia Region have an unmet need for family planning services; $17.1 \%$ for spacing, $11.8 \%$ for limiting, and only $28.6 \%$ women have received family planning services. The total demand for family planning in Oromia Region was 57.55\% [7]. However, the percentage of married women with unmet needs for family planning has been declining over time, from $37 \%$ in 2000 to $22 \%$ in 2016 . At the same time, the proportion of married women using modern contraceptive methods has increased sharply from 8\% in 2000 to $36 \%$ in 2016 [7].

Meeting the unmet needs for family planning in subSaharan Africa could make an important contribution to improving maternal health through early studies or initiatives. In 2008, the estimated maternal mortality ratio in sub-Saharan Africa was 596 per 100,000 live births, the contraceptive prevalence was $22 \%$, and the proportion of maternal deaths averted by contraceptive use was estimated at $32 \%$. In contrast, among low-and-middleincome countries as a group, the maternal mortality ratio was 273 , the contraceptive prevalence was $63 \%$, and $44 \%$ of maternal deaths were estimated to be averted by family planning use [8].
The potential for contraceptives to reduce unintended pregnancies among women living with HIV-thereby contributing to the Prevention of Mother-to-Child Transmission (PMTCT) and reduced maternal morbidity and mortality-does not seem to be adequately empirically investigated, especially in terms of practitioners' involvement in enhancing this practice. According to a study conducted in Ethiopia on HIV and family planning service integration at Voluntary HIV counseling and testing (VCT) among married and other sexually active women, $40 \%$ were using contraceptives. Of women in current sexual unions, $17 \%$ had unmet needs for family planning and were having unprotected sex [9].

It is seemingly not possible to reach the 2020 targets for reducing new pediatric HIV infections in high disease-burdened countries unless the unmet need for family planning among women living with HIV is dealt with [10]. People with HIV often desire a child or more children, and $20-60 \%$ have an HIV-negative partner $[10,11]$. In sub-Saharan Africa, women are the HIVpositive partner in about half of discordant partnerships [12]. The WHO thus recommends that people with HIV who have serodiscordant partners be given the option of immediately starting ART to reduce sexual transmission and facilitate safe conception. It will also contribute to preventing new HIV infections among men and women [13]. Programs that have succeeded in promoting condom use and providing HIV prevention and treatment services in this region have largely missed the opportunity to address the contraceptive needs of the key populations they serve. Therefore, the research statement for this study is "What the unmet need for family planning of women of reproductive age living with HIV attending healthcare facilities in Oromia Region, Ethiopia?".

\section{Methods and materials Study setting}

This study was conducted in Ethiopia at Oromia regional state surroundings Finfinne/Addis Ababa. Finfinne referring to the parts of the Oromia region just neighboring the national capital and the capital city was not included. Finfinne was the original name in Afan Oromo language and it's the capital city of Oromia regional state as well. The study zone is served by 27 health centers, 13 of which provided both ART and family planning services. The remaining 14 health centers provide family planning and all other maternal neonatal child health services except ART services. The total number of people living with HIV enrolled at ART clinics in the zone was 9421, of which 2380 were women of reproductive age (Office Finfinne Special Zone 2018:6) [20]. 


\section{Sampling procedure}

All health centres found in the Special Zone of Oromia Regional state that provide both ART and family planning services were identified and randomly selected by computer-generated methods to be included in the study (5 Health centres were selected from 13 health centres). Of total reproductive age women attending ART and FP in the zone (2380), 65.4\% (1557) are attended at five randomly selected health centers.

A list of all Reproductive age women living with HIV randomly selected Health facility, age between 18 and 49 years of age, who had attended ART follow-up services for at least 6 months from randomly selected healthcare facilities were created. The prepared sampling frame was prepared and entered into SPSS version 23 by using their pre-ART registration number from the health management information system (HMIS) database. A simple random sampling technique by computer-generated samples was utilized at each health centre to select a total of 670 study respondents by proportionally allocated five randomly selected health centres, based on their total number of ART clients based settled criteria.

\section{Study design}

A health facility-based cross-sectional study design was conducted among Reproductive age women living with HIV attending both ART and Family planning clinics.

\section{Sample size determination}

The sample size was determined through a single population proportion formula by using a case study found in integrated sites in Ethiopia, where $40 \%$ of women were family planning users $(\mathrm{P})$ [14]. By considering the design effect of 2, with correction formula since the total population was less than 10,000 (2380) and with a 5\% nonresponse rate considered, the final sample size was 670 women living with HIV.

\section{Data collection}

The questionnaire used for data collection was initially prepared in English, and translated to Afan Oromo, and back to English for language experts to confirm its consistency. The questions included in the questionnaire were adapted and prepared by reviewing different related literature and variables identified to be measured. The training was given to data collectors and supervisors by the primary researcher for 2 days. Data collectors crosschecked the pre-ART card numbers of women living with HIV who came to the ART clinic with sampled card numbers daily. Five trained data collectors collected data from women of reproductive age. The completed questionnaires were collected and checked daily for consistency and completeness by supervisors and the primary researcher. Data were collected using a pre-tested structured Afan Oromo version of the questionnaire. A pretest of the questionnaire was done on $5 \%$ of the women living with HIV at Ambo health center, to identify any ambiguity, to confirm consistency in the questionnaire, to determine acceptability, and to make necessary corrections 1 week before the actual data collection process. The respondents were guided through a questionnaire and chart abstraction conducted at their health facility by trained data collectors.

\section{Operational definition}

According to this demand for family planning consists of women with meet need for FP who are using a contraceptive method to achieve their reproductive goals; unmet need, consists of women with an apparent demand for FP who are not using contraception/family planning [3]. Two different models were fitted to investigate the factors predicting the met need demand for family planning.

\section{Methods of analysis}

The returned questionnaires were checked for completeness, cleaned manually, coded and entered into EPI INFO 7.1.6 version, and then transferred to SPSS version 23 for further analysis. Frequencies, percentages, mean and standard deviation (SD) were used to summarise descriptive statistics of the data and text. Moreover, tables and graphs will be used for data presentation. Bivariate analysis was used primarily to check which variables have an individual association with the dependent variable. This cross-sectional study surveyed women living with HIV in Oromia, Ethiopia to determine whether they expressed met demand need for family planning evidence on the logistic regression modelling was undertaken to examine the net effects of a set of explanatory variables over the outcome variables and COR, which were adjusted for all other variables at $95 \%$ CIs. In this analysis, the outcome variables, the demand for family planning were dichotomized with "1" being needs met and " 0 " being an unmet need for family planning. Two different models were fitted to investigate the factors predicting the demand for family planning. Accordingly, the HL test for the following two models showed Chi-square p-values $>0.05$, which proved the goodness-of-fit of the applied models for this study at $\mathrm{p}=0.81$ for the demand of family planning model. This study revealed that based on the stated criteria the factors that were identified through binary logistic regression were family monthly income; discussion with healthcare providers about family planning; previous pregnancy; future fertility desire; and the number of sexual partners. These identified variables were entered into multiple logistic regression analyses to identify independent predictors of met need demands for family 
planning. Variables that were found to have an association with the dependent variables were then entered into multiple logistic regressions to control the possible effect of confounders. Finally, the variables which have significant association were identified based on AOR, with a 95\% CI and p-value to fit into the final regression model.

\section{Result}

The complete response rate of this study was $654 / 670$ (97.6\%).

There were 654 respondents whose ages ranged between 18 and 49 years. The mean age of the respondents was 31.86 years with an SD of \pm 6.0 years as reflected in Table 1.

Table 1 presented the education status of the respondents which revealed that the literacy proportion was 409 (62.5\%). The majority of study participant's religious affiliation $474(72.5 \%)$ belonged to the orthodox denomination,

Of the 609 (93.1\%) employed respondents, 256 (39.1\%) were housewives and only 59 (9.0\%) were working for the public service sector. The family's monthly income distribution among the respondents was assessed, and it was found that on average, the income was 1398.18 Ethiopian Birr (50\$), and ranged from 100 to 5000. More than 357 (54.6\%) respondents were earning less than 1201 Ethiopian birr $(1 \$=27.84$ Birr $)$ see in Table 1 for details.
The magnitude of met need demand for family planning of women living with HIV $(\mathrm{N}=654)$

The met need demand for family planning was measured by the summation of those who had met their needs for family planning, and those who had unmet family planning needs among sexually active women of reproductive age.

The demand for family planning among women of reproductive age living with HIV was 630 (96.3\%), at 95\% CI of 94.8 to $97.7 \%$, of which 530 (84\%) had meet needs for family planning. The prevalence of unmet need for family planning was determined $100(16 \%)$ of target populations had unmet needs for family planning while attending monthly ART drug refilling and follow-up programs at Health facilities which ranges from 13 to $19 \%$ at 95\% CI see in Fig. 1.

\section{Factors associated with met need demand for family planning using multivariable logistic regression}

This study revealed that based on the stated criteria the factors that were identified through binary logistic regression were family monthly income; discussion with healthcare providers about family planning; previous pregnancy; future fertility desire; and the number of sexual partners. These identified variables were entered into multiple logistic regression analyses to identify independent predictors of met need for family planning. Variables that were found to have an association with the dependent variables were then entered into multiple logistic

Table 1 Demographic and socioeconomic characteristics of respondents in Oromia Region, Ethiopia 2018 (N=654)

\begin{tabular}{|c|c|c|c|}
\hline Demographic and social characteristics & Category & Frequency (\%) & Cumulative (\%) \\
\hline \multirow[t]{3}{*}{ Age in year $(n=654)$ Mean $(S D): 31.86( \pm 6.0)$} & $18-25$ & $96(14.7)$ & 14.7 \\
\hline & $26-35$ & $374(57.2)$ & 71.9 \\
\hline & $36-49$ & $184(28.1)$ & 100.0 \\
\hline \multirow[t]{4}{*}{ Highest level of education } & Never been school & $245(37.5)$ & 37.5 \\
\hline & Primary & $284(43.4)$ & 80.9 \\
\hline & Secondary & $106(16.2)$ & 97.1 \\
\hline & College/University & $19(2.9)$ & 100.0 \\
\hline \multirow[t]{5}{*}{ Employment status } & Government employee & $59(9.0)$ & 9.0 \\
\hline & Merchant/Private work & $239(36.5)$ & 45.6 \\
\hline & Housewife & $256(39.1)$ & 84.7 \\
\hline & Farmers & $55(8.4)$ & 93.1 \\
\hline & Unemployed & $45(6.9)$ & 100.0 \\
\hline \multirow[t]{5}{*}{ Marital status } & Married & $528(80.7)$ & 80.7 \\
\hline & Cohabit/living together & $51(7.8)$ & 88.5 \\
\hline & Divorced/separated & $46(7.0)$ & 95.5 \\
\hline & Widowed & $22(3.4)$ & 98.9 \\
\hline & Single & $7(1.1)$ & 100 \\
\hline \multirow[t]{2}{*}{ Residence } & Urban & $518(79.2)$ & 79.2 \\
\hline & Rural & $136(20.8)$ & 100.0 \\
\hline
\end{tabular}




\section{Demand FP}

Met Need of FP $\quad$ Unmet Need of FP

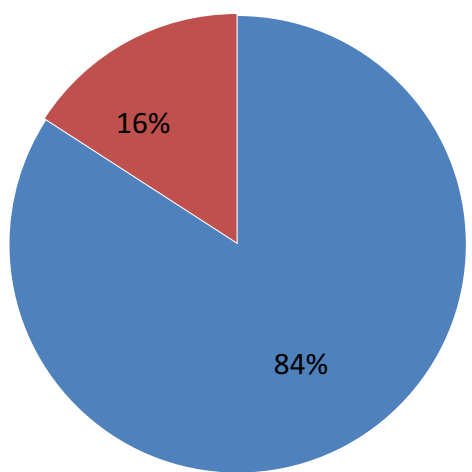

Fig. 1 Magnitude of met need and unmet need demand for family planning among HIV-infected women 2018

regressions to control the possible effect of confounders. Finally, the variables which have significant association were identified based on AOR, with a $95 \% \mathrm{CI}$ and p-value to fit into the final regression model.
According to the contents of Table 2, the respondents who had heard about family planning during ART follow-up had 35.8 times higher odds of meet need for FP as compared with had not heard family planning during follow up.

Reproductive age women who had discussions with healthcare providers during follow up were 4.3 times higher odds of meet need for FP as compared with had not discussed FP needs during follow up. The study further reveals that those who had one or a single partner had 7.24 times higher odds of meet need for FP as compared with to those who had two and above sexual partners.

Respondents whose last pregnancy was intended had 3.07 times higher odds of meet need for family planning, and those who had fertility desire to have more children in the future were 2.15 times higher odds of meet need for family planning compared to those who had no intentions for pregnancy and had no fertility desire, respectively.

Table 2 Factors associated with met need for family planning at multivariable logistic regression (AOR, 95\% Cl) in Oromia, Ethiopia 2018

\begin{tabular}{|c|c|c|c|}
\hline \multirow{2}{*}{$\begin{array}{l}\text { Factors associated with demand for family } \\
\text { planning }\end{array}$} & \multicolumn{2}{|l|}{ Demand for family planning } & \multirow[t]{2}{*}{ AOR $(95 \% \mathrm{Cl})$} \\
\hline & Met need for family planning & Unmet need for family planning & \\
\hline \multicolumn{4}{|l|}{ Ever heard family planning services } \\
\hline Yes & $528(80.7)$ & $105(16.1)$ & \multirow[t]{2}{*}{$35.8(7.48-171.4)^{* * *}$} \\
\hline No & $2(0.3)$ & $19(2.9)$ & \\
\hline \multicolumn{4}{|l|}{ Discussed with healthcare } \\
\hline Yes & $470(71.9)$ & $73(11.2)$ & \multirow[t]{2}{*}{$4.326(2.56-7.32)^{* * *}$} \\
\hline No & $60(9.2)$ & $51(7.8)$ & \\
\hline \multicolumn{4}{|l|}{ Have partner } \\
\hline Yes & $521(79.7)$ & $103(15.7)$ & \multirow[t]{2}{*}{$5.26(1.79-15.5)^{* * *}$} \\
\hline No & $9(1.4)$ & $21(3.2)$ & \\
\hline \multicolumn{4}{|l|}{ Number of sexual partners } \\
\hline None/zero & $7(1.1)$ & $18(2.8)$ & $10.04(3.49-28.84)^{* * *}$ \\
\hline One & $507(77.5)$ & $94(14.4)$ & \multirow[t]{2}{*}{$7.24(1.82-28.74)^{* * *}$} \\
\hline Two and above & $16(2.4)$ & $12(1.8)$ & \\
\hline \multicolumn{4}{|l|}{ Last pregnancy wanted/timed } \\
\hline Yes & $443(67.7)$ & $71(10.9)$ & \multirow[t]{2}{*}{$3.07(1.84-5.12)^{* * *}$} \\
\hline No & $87(13.3)$ & $53(8.1)$ & \\
\hline \multicolumn{4}{|l|}{ Fertility desire } \\
\hline Yes & $256(39.1)$ & $68(10.4)$ & \multirow[t]{2}{*}{$2.15(1.31-3.51)^{* *}$} \\
\hline No & $274(41.9)$ & $56(8.6)$ & \\
\hline
\end{tabular}

Cl confidence interval, $A O R$ adjusted

${ }^{* * *} \mathrm{p}<0.001,{ }^{* *} \mathrm{p}<0.01,{ }^{*} \mathrm{p}<0.05$ 


\section{Discussion}

This study determined the magnitude of demand for family planning among HIV-infected women and established that the demand was 630 (96.3\%), of which 530 (84\%) had met the need for family planning, followed by $16 \%$ who had unmet needs in terms of family planning while attending monthly ART drug refilling with identified factors that affected met the need of family planning for reproductive-age women.

The socioeconomic characteristics of the respondents as summarised in Table 1 are not different from the socioeconomic profile of Ethiopia. For example, in the general population of the same region, Christian denominations dominate and represent $65 \%$ of the population, $79.2 \%$ resided in urban areas, and the largest ethnic group is Oromo, followed by Amhara which represent $64 \%$ of the population 7 . The results are also similar in terms of the proportion of women who are currently married or living together with a partner ( $88.5 \%$ vs $65 \%)$ of women of ages $18-49$ years in the region [7].

\section{The met need demand for family planning among HIV-infected women}

One critical component of family planning and HIV integration that has significant positive health outcomes was to ensure that all women living with HIV have access to both a full range of contraceptives based on demand and safe pregnancy counselling [2]. This study determined the demand for family planning needs among women of reproductive age living with HIV was $96.3 \%$ with a $95 \%$ CI of 94.8 to $97.7 \%$ in the study area. This finding was supported by other studies which revealed that $92.6 \%$ of women living with HIV need family planning services [15].

On the other hand, these findings were higher than the general population of Ethiopia and the Oromia Region as evidenced by the demand for family planning is $58 \%$ [7: p. 20]. This might be due to the contribution of partnerships like PEPFAR and the United Nations Population Fund (UN family planning A) which supported preservice training on family planning/HIV integration in the emergency surgical officer program, and the health extension worker program in Ethiopia [2]. There is evidence that suggests that a contribution of some family planning methods should increase demand for family planning. For instance, condom use increased from 5.7\% pre-HIV to $71.7 \%$ post-HIV, with $89.6 \%$ of clients reporting regular use [16]. Therefore, this indicates the need for developing national guidelines/strategies and training for integrating family planning services into facility-based care for women living with HIV [17].
This study identified that $16 \%$ of women of reproductive age living with HIV had an unmet need for family planning while attending monthly ART drug refilling and follow-up programs. These findings concur with previous studies conducted in Kenya, which reported that $19 \%$ of clients who had been sexually active in the past month had an unmet need for family planning [18]. However, this was lower than the national general population, which indicated that the unmet need for family planning was 22\% in Ethiopia [7: p. 20]. This result informs us that there is an unmet need for family planning among HIV-infected women, underlining a gap in the national PMTCT of HIV strategy.

This study identified factors that might be responsible for an increased met need demand for family planning during follow-up as being: a discussion with healthcare providers during follow-up; the number of sexual partners; last pregnancy planned; and fertility desire for more children in the future. The finding was supported by a study conducted in South Ethiopia [19], which revealed that factors that were significantly associated with the unmet need for family planning among women living with HIV were age, educational status, desired children, family planning not being used previously, not receiving family planning on the day of interview at HIV/ AIDS care, and not being on ART. Therefore, future developments of national guidelines/strategies and training modules of family planning and HIV would be integrated family planning services into facility-based care for women living with HIV should consider these identified factors to increase the availability of family planning among women of reproductive age living with HIV.

\section{Limitation of the study}

Though the problem of recall bias was minimized by conducting exit interviews; the current study is not free of social desirability bias in which some mothers may report the service as positive experiences while they are in the health facilities. As a strength, the study tried to cover a large number of health facilities including health centers and large sample size.

\section{Conclusion and recommendation}

The overall demand for family planning was $96 \%$ among the women living with HIV, and that $16 \%$ of women had an unmet need for family planning. The authors conducted a logistic regression and find various dependent variables that are associated with the met need for family planning services, such as having discussions with healthcare providers, having a partner and previous pregnancy; future fertility desire, the last pregnancy being intended. It was established that high met need demand for family planning among HIV-infected women. 
These results are interpreted to suggest that clear policy implications of family planning must be better integrated into ART clinics an important conclusion of this study result.

Policymakers would be better considers the future developments of national guidelines/strategies and training modules of family planning and HIV would be integrated family planning services into facility-based care for women living with HIV should consider these identified factors to increase the availability of family planning among women of reproductive age living with HIV.

Integrated family planning/HIV services contribute to the national family planning programs to provide full access to a variety of contraceptive methods so that couples and individuals can obtain the method that best suits their needs. The main contribution of the study to the level of health policy is as follows:

- Satisfy unmet needs and intention to use a method so that those wanting to use a method can do so.

- Provide quality counselling to improve the knowledge of reproductive-aged and empowered women by service providers on the integrated family planning/HIV services.

- Healthcare providers should be trained, equipped, and encouraged to take ownership of the implementation of the reproductive-aged women-centred integrated family planning /HIV strategic plan.

- After the implementation of the final strategic plan, the integration of family planning and HIV services should lead to an increase in the utilization of family planning, dual contraceptive methods, the need for family planning being met, prevent repeated unwanted pregnancy, and offer HIV services. This will ultimately improve the quality of life of reproductive-aged women, the community, and families at large by reducing unmet need for family planning.

- Policymakers would better establish women-centered integrated family planning with HIV service could facilitate that the met need for family planning services of reproductive age women living with HIV.

\footnotetext{
Abbreviations

AIDS: Acquired immune deficiency syndrome; ART: Antiretroviral therapy; AOR: Adjusted odd ratio; CSA: Central Statistical Agency; Cl: Confidence interval; COR: Crude odd ratio; DHS: Demographic Health Survey; EDHS: Ethiopian Demographic Health Survey; FHI: Family Health International; FMOH: Federal Ministry of Health; HIV: Human immuno-deficiency virus; IUDs: Intra uterine devices; OR: Odds ratio; ORHB: Oromia Regional Health Bureau; PMTCT: Prevention of Mother-to-Child Transmission; STIs: Sexually transmitted infections; UNAIDS: United Nations Programme on HIV/AIDS; UNICEF: United Nations International Children's Emergency Fund; UNISA: University of South Africa;
}

USAID: United States Agency for International Development; VCT: Voluntary HIV counseling and testing; WHO: World Health Organization.

\section{Acknowledgements}

We want to acknowledge the University of South Africa (UNISA) for giving us this opportunity. Our deepest gratitude goes to study participants, Ambo University, College of medicine and health sciences, Oromia Region Health Bureau, special zone surroundings of Finfinne Health office, supervisors, and data collectors for their support. Finally, we would like to express my gratitude to all participants who volunteered participated in the study.

\section{Authors' contributions}

All authors made substantial contributions to conception and design, acquisition of data, or analysis and interpretation of data; took part in drafting the article or revising it critically for important intellectual content; gave final approval of the version to be published; and agree to be accountable for all aspects of the work. All authors read and approved the final manuscript.

\section{Funding}

Funding for this study was obtained from Ambo University. The university had no role in the design of the study and collection, analysis, and interpretation of data.

Availability of data and materials

Datasets used in the current study are available from the corresponding author upon reasonable request.

\section{Declarations}

\section{Ethics approval and consent to participate}

The researcher submitted a letter seeking ethical approval and permission to conduct the study from the University of South Africa, and obtained ethical clearance (Ref.No HSHDC/710/2017), then submitted it to the Research and Technology Transfer Core-process of Oromia regional health Bureau (ORHB) and received approval (Ref.No BEFO/HBT64/18/2564). Thereafter, a letter of permission to conduct this research was also obtained from the ORHB who requested support for the researcher from each study site to facilitate the data collection process (Ref.No BEFO/HBT64/18/2569). Informed consent from each study participant was obtained after the nature of the study was fully explained in their local languages as was attached in the questionnaire. The respondents' right to refuse or withdraw from the study at any stage was respected. Information collected from respondents was kept confidential, and the collected information was stored in a locked space, in a file without the name of the study respondent (anonymously), but codes were assigned for each respondent and have not been disclosed to others except the principal investigators. Scientific integrity was ensured by avoiding plagiarism, being honest in reporting on the findings, and accurately citing all consulted sources.

A formal letter of cooperation was written to all selected Health institutions. Written informed consent was obtained from study participants after fully explaining the nature of the study in their local languages as is attached in the questionnaire. The collected information was kept confidential without the name of the study participants.

\section{Consent to publish}

Not applicable.

\section{Competing interests}

Authors declared that they have no competing interest.

\section{Author details}

${ }^{1}$ Department of Health Studies, College of Human Science, University of South Africa, Regional Learning Office Ethiopia, Addis Ababa, Ethiopia. ${ }^{2}$ St. Paul's Hospital Millennium Medical College, Addis Ababa, Ethiopia. ${ }^{3}$ Department of Midwifery, College of Medicine and Health Sciences, Ambo University, Ambo, Ethiopia. ${ }^{4}$ Department of Public Health, College of Human Science, University of South Africa, Pretoria, South Africa.

Received: 18 August 2021 Accepted: 30 October 2021

Published online: 13 November 2021 


\section{References}

1. Wilcher R, Cates W. Reproductive choices for women with HIV. Bull World Health Organ. 2009;87:833-9.

2. Johnston B, Ligiero D, DeSilva S, Medley A, Nightingale V, Sripipatana T, et al. Meeting the family planning needs of women living with HIV in US government global health programs. AIDS (Lond, Engl). 2013;27(01):S121.

3. ANALYTICAL D. REVISING UNMET NEED FOR FAMILY PLANNING. 2012

4. Orner PJ, de Bruyn M, Barbosa RM, Boonstra H, Gatsi-Mallet J, Cooper DD. Access to safe abortion: building choices for women living with HIV and AIDS. J Int AIDS Soc. 2011;14(1):1-9.

5. Darroch JE, Singh S. Trends in contraceptive need and use in developing countries in 2003, 2008, and 2012: an analysis of national surveys. Lancet. 2013;381(9879):1756-62.

6. Sarnquist C, Rahangdale L, Maldonado Y. Reproductive health and family planning needs among HIV-infected women in Sub-Saharan Africa. Curr HIV Res. 2013;11(2):160-8.

7. Csa I. Central statistical agency (CSA) [Ethiopia] and ICF. Ethiopia demographic and health survey, Addis Ababa, Ethiopia and Calverton, Maryland, USA. 2016.

8. Ahmed S, Li Q, Liu L, Tsui AO. Maternal deaths averted by contraceptive use: an analysis of 172 countries. Lancet. 2012;380(9837):111-25.

9. Bradley H, Bedada A, Tsui A, Brahmbhatt H, Gillespie D, Kidanu A. HIV and family planning service integration and voluntary HIV counselling and testing client composition in Ethiopia. AIDS Care. 2008;20(1):61-71.

10. Mahy M, Stover J, Kiragu K, Hayashi C, Akwara P, Luo C, et al. What will it take to achieve virtual elimination of mother-to-child transmission of HIV? An assessment of current progress and future needs. Sex Transm Infect. 2010;86(Suppl 2):ii48-55.

11. Kaida A, Laher F, Strathdee SA, Janssen PA, Money D, Hogg RS, et al. Childbearing intentions of HIV-positive women of reproductive age in Soweto, South Africa: the influence of expanding access to HAART in an HIV hyperendemic setting. Am J Public Health. 2011;101(2):350-8.

12. Matthews LT, Crankshaw T, Giddy J, Kaida A, Smit JA, Ware NC, et al. Reproductive decision-making and periconception practices among
HIV-positive men and women attending HIV services in Durban, South Africa. AIDS Behav. 2013;17(2):461-70.

13. Eyawo O, de Walque D, Ford N, Gakii G, Lester RT, Mills EJ. HIV status in discordant couples in sub-Saharan Africa: a systematic review and metaanalysis. Lancet Infect Dis. 2010;10(11):770-7.

14. Scholl E, Cothran D. Integrating family planning and HIV services. Programs in Kenya and Ethiopia lead the way Case Study Series. Arlington: USAID's AIDS Support and Technical Assistance Resources, AIDSTAR-One, Task Order. 2011;1.

15. Heffron R, Mugo N, Ngure K, Celum C, Donnell D, Were E, et al. Hormonal contraceptive use and risk of HIV-1 disease progression. AIDS (Lond, Engl). 2013;27(2):261.

16. Joshi B, Velhal G, Chauhan S, Kulkarni R, Begum S, Nandanwar Y, et al. Contraceptive use and unintended pregnancies among HIV-infected women in Mumbai. Indian J Community Med. 2015;40(3):168.

17. Johnson KB, Akwara P, Rutstein SO, Bernstein S. Fertility preferences and the need for contraception among women living with HIV: the basis for a joint action agenda. AIDS (Lond, Engl). 2009;23:S7-17.

18. McCarraher D, Cuthbertson C, Kung'u D, Otterness C, Johnson L, Magiri G. Sexual behavior, fertility desires and unmet need for family planning among home-based care clients and caregivers in Kenya. AIDS Care. 2008;20(9):1057-65.

19. Feyssa M, Tsehay Y, Tadesse A. Unmet need for family planning among women in HIV/AIDS care at antiretroviral treatment clinic in South Ethiopia: a challenge to prevention of mother to child transmission. J AIDS Clin Res. 2015;6(6).

20. Office Finfinne Special Zone. 2018. Sociodemographic data of Finfine special zone. Unpublished source

\section{Publisher's Note}

Springer Nature remains neutral with regard to jurisdictional claims in published maps and institutional affiliations.
Ready to submit your research? Choose BMC and benefit from:

- fast, convenient online submission

- thorough peer review by experienced researchers in your field

- rapid publication on acceptance

- support for research data, including large and complex data types

- gold Open Access which fosters wider collaboration and increased citations

- maximum visibility for your research: over $100 \mathrm{M}$ website views per year

At BMC, research is always in progress.

Learn more biomedcentral.com/submissions 